\title{
HISTORY OF OPHTHALMOLOGY
}

\author{
DANIEL ALBERT, EDITOR
}

\section{From Von Graefe's Clinic to the Ecole des Beaux-Arts. The Meteoric Career of Richard Liebreich}

\author{
JAMES G. RAVIN, M.D. ${ }^{1}$ AND CHRISTIE KENYON, Ph.D. CANDIDATE ${ }^{2}$ \\ ${ }^{1}$ Toledo, Ohio, and ${ }^{2}$ Department of the History of Art, University of Michigan, \\ Ann Arbor, Michigan
}

\begin{abstract}
Richard Liebreich was a student of Helmholtz and took one of the first ophthalmoscopes to von Graefe's clinic. While von Graefe's assistant in Berlin, he created the first atlas of ophthalmoscopy. Liebreich moved to Paris, where he achieved great success, due in part to successful surgery on Emperor Napoleon III's mother-in-law. After the fall of Napoleon in 1870, Liebreich moved to London, where he became the head of ophthalmology at St. Thomas hospital and medical school. Following several personal attacks in the medical literature, Liebreich returned to Paris, where he gradually retired from practice, yet continued a creative life as a sculptor, painter, and researcher in artistic technique. (Surv Ophthalmol 37:221-229, 1992)
\end{abstract}

Key words. history - Liebreich, Richard - medicine and art • ophthalmoscope

This is a tale of discovery and mystery, but, unhappily, very little romance. It is the story of a man who reached the highest ranks of ophthalmology in Berlin, Paris, and London, only to desert ophthalmology for the fine arts.

Richard Liebreich's (Figs. 1-3) importance is evident from his achievements. He is best known as the creator of the first atlas of ophthalmoscopy (Fig. 4). The first edition of this book was published simultaneously in Berlin and Paris in 1863, with the text in German and in French, side by side. ${ }^{11}$ Editions in English and Spanish followed. The atlas spread knowledge obtained from study of the living human eye, which followed Helmholtz' landmark invention of the ophthalmoscope in 1851. Liebreich designed and painted the illustrations for the atlas.

Liebreich was also an innovator in ophthalmic instrumentation. As a medical student, he was taught by Helmholtz. He took one of Helmholtz' original ophthalmoscopes to von Graefe in 1852, the year following its invention. Helmholtz' direct ophthalmoscope employed four thin plates of glass as a semitransparent mirror to reflect light into the eye. The instrument was novel, but not very practical. The illumination was poor, and it was difficult to use. In 1854 Liebreich created the first ophthalmoscope utilized for demonstration purposes. ${ }^{4}$ This was an indirect ophthalmoscope on a stand, with a chin rest and a head support. The reflector was a concave mirror. The teacher could adjust the instrument and the student could then look into the subject's eye. In 1860 Liebreich designed the first small handheld ophthalmoscope (Fig. 5), with a frame for a corrective lens, which could be flipped in front of 


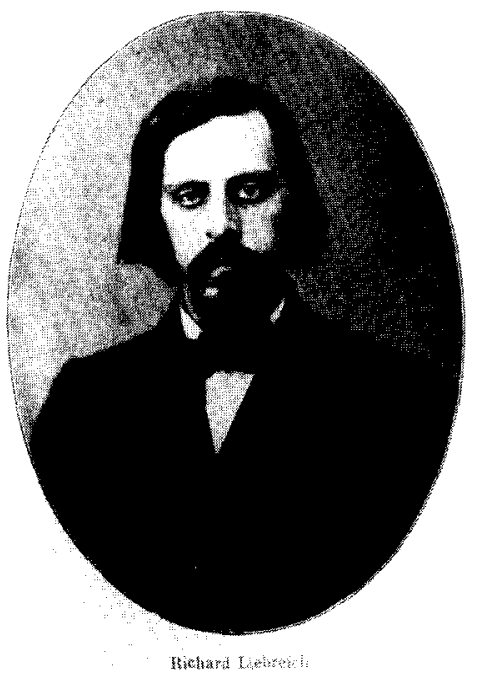

Fig. 1. Richard Liebreich, photograph from Handbuch der Gesamten Augenheilkunde $v$ Graefe und Saemisch. ${ }^{7}$

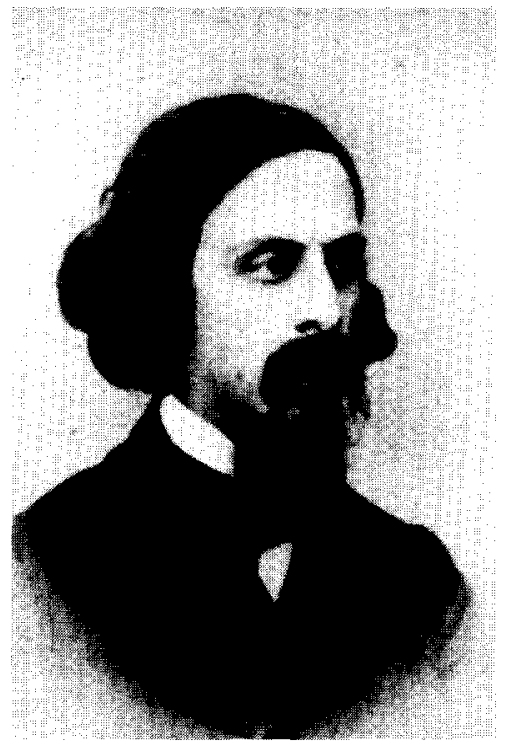

Fig. 2. Richard Liebreich, photograph. (Courtesy of Stanley Burns, M.D., and the Burns Archive.)

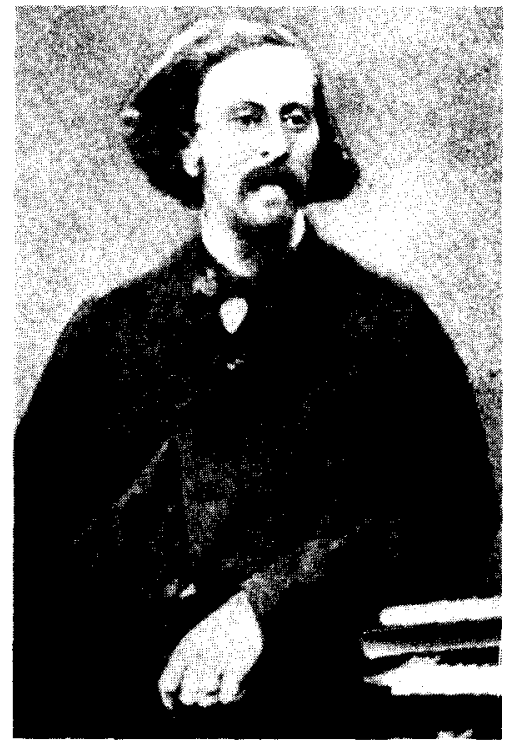

Fig. 3. Richard Liebreich, photograph from his obituary, Klin Bl Augenheilkd 58:567, 1917. the mirror. He also devised a binocular corneal microscope, which was in use by $1872 .^{5}$ This was a forerunner of Gullstrand's slit-lamp microscope, which was first demonstrated in 1911.

Liebreich was also a pioneer in fundus photography. Others had made attempts to photograph the interior of the living human eye as early as 1862 , but no details are available about those attempts. ${ }^{6}$ Film was extremely slow, exposure times were very long, and illumination was poor. In 1874 Liebreich showed how his ophthalmoscope on a stand could be used for fundus photography. ${ }^{15}$

In addition, the first report of genetics in ophthalmology is considered to be Liebreich's publication on retinitis pigmentosa of 1861 , in which he described several cases of consanguity. ${ }^{17} \mathrm{All}$ in all, Liebreich made major contributions to 19th century ophthalmology.

\section{The Early Years}

Liebreich was born in Königsberg, Prussia, June 30, 1830. He studied medicine in Konigsberg, Berlin, and Halle, and graduated at Halle in 1853. He then spent several months with Donders in Utrecht and with Brücke in Berlin.

Liebreich was in the right place at the right time. In his own words, "I had the good fortune to be associated with our great physiologist Helmholtz as his assistant, when, in 1851 he in- vented the ophthalmoscope in Konigsberg, and thus I first became acquainted with it through the inventor himself. I soon afterwards in Berlin made the acquaintance of $A$. von Graefe, who was just then commencing his brilliant carcer." ${ }^{11} \mathrm{Be}-$ tween 1854 and 1862, he was an assistant at von Graefe's clinic in Berlin. He wrote, "With him, and on his patients, I made the first practical applications of the new instrument." ${ }^{11}$ The early issues of von Graefe's Archiv fur Ophthalmologie include many of Liebreich's original engravings and retinal paintings. ${ }^{14}$

Here is a fascinating description of Liebreich at von Graefe's clinic written by an American ophthalmologist, Hasket Derby of Boston:

"He was by far the brightest man on the staff: performed all the ophthalmoscopic and refractive work and gave all the ophthalmoscopic courses. Rather short and thin, with long hair ... and always clad in a dress suit, he exactly resembled a dancing master temporarily deprived of his fiddle: he was said to be an artist of no mean ability. Of his preeminent skill with the ophthalmoscope it is unnecessary for me to speak; his atlas tells the story. ${ }^{2}$

\section{The Move to Paris}

Now to the small amount of romance in this tale.

In 1862 Liebreich moved to the French capital, for reasons that are not entirely clear. $\Lambda$ large colony of German physicians was present in Par- 


\section{ATLAS \\ IIFR \\ OPHTHALMOSCOPIE.}

\author{
DARSTELLUNG DES AUGRNGRUNDES

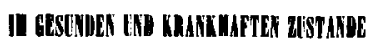 \\ 12 TAPELN YIT 67 FIGUREN IN FARBENDRUCR. \\ NACH DER YATUR GEMALT UND ERLAEUTRRT \\ rvis \\ D\& RICHARD LIEBREICH.
}

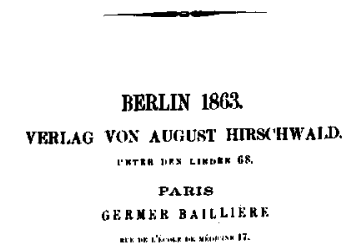

\section{ITLAS \\ DOPHTIIAL MOSCOPIE}

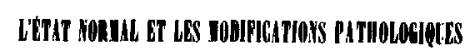 \\ DU FOND DE L'CEI, VISLHLES A LOPHTALMOSCOPE \\ coupssex \\ DE I2 PI,ANCHES LONTENANT' IT FLGURES

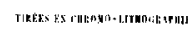

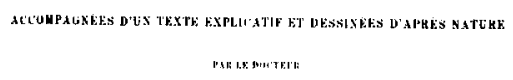 \\ RICHARI) LIEBREICH
}

Fig. 4. Atlas der Ophthalmoscopie, title page of the French/German edition.

is. The German Medical Society of Paris had been in existence for over twenty years, and Liebreich became its president. ${ }^{16}$

Liebreich's wife may have had something to do with the decision to move to Paris. She was a niece of Ludwig Bamberger (1823-1899), the famous German banker, politician, and economist. Bamberger was involved in the revolution of 1848 in Germany, fled the country, and was condemned to death in absentia. ${ }^{22}$ During his exile in Paris, Bamberger opened his home regularly to a cosmopolitan social network, and Liebreich was a frequent guest.

When Liebreich told von Graefe of his plan to move to Paris, von Graefe encouraged him and offered letters of recommendation, but Liebreich refused, saying, "I have no need of recommendations!" Liebreich had many friends and quickly achieved success in Paris.

The pinnacle of his career in Paris occurred when the mother of Empress Eugenie consulted Liebreich. She suffered from acute glaucoma, with loss of visual field in her right eye. On July 4 , 1865 , Liebreich performed an iridectomy on this eye, and one week later did the same for the other eye. The surgery and postoperative course were uncomplicated. This was a stupendous success for Liebreich. Theodor Leber, one of Lie- breich's assistants at that time, described the events in his diary. Leber was very impressed by Empress Eugenie's beauty (Fig. 6) and by Napo-

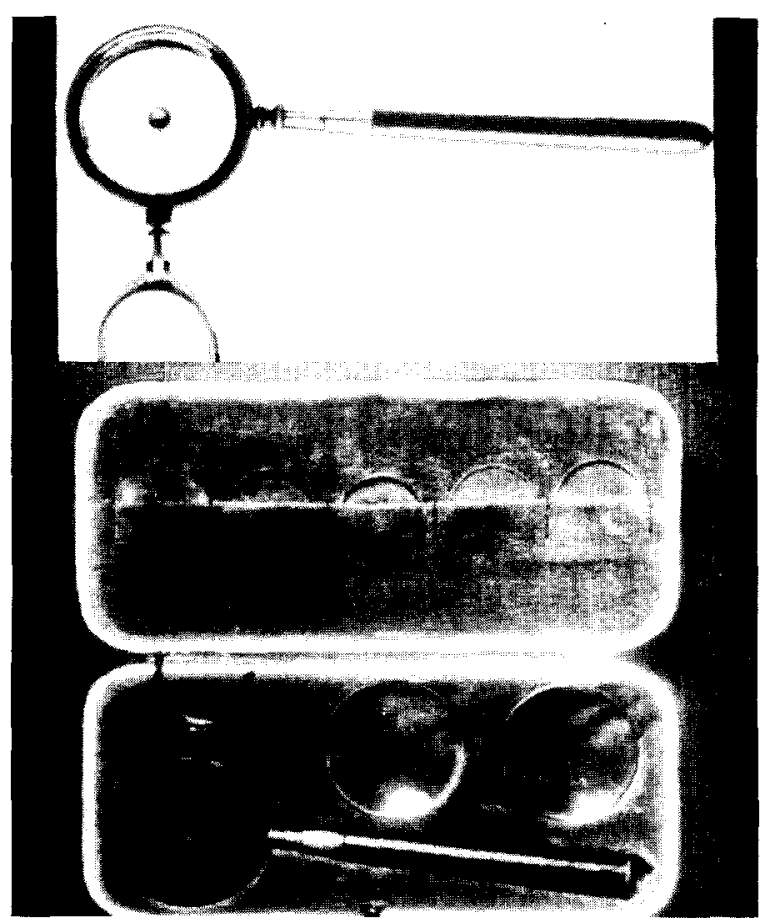

Fig. 5. Liebreich's ophthalmoscope. 
leon's affability. The Emperor "ignored with friendly nonchalance" the fact that Liebreich was introduced to him in shirt sleeves. ${ }^{8}$

Some said Liebreich was merely lucky, but Landolt, ${ }^{10}$ the distinguished French ophthalmologist, defended him: "The word luck is a bit inappropriate. It was not luck that occurred. Certainly for Liebreich it was a bit of luck that the patient was struck with a form of glaucoma treatable by iridectomy. But for the mother-in-law of the Emperor to come to him, it was necessary all the same, to be someone. And then it was necessary for him to make the diagnosis, to choose the remedy, to have it accepted, and finally to perform a rather delicate operation with courage and skill in a period in which its efficacy was still little known. In summary, if there were luck in this affair, it was above all for the patient.

This oculist suddenly saw the doors of the Tuileries palace open to him. We observed this strange man with curiosity, his narrow Shylock-like face, the black rings under his brilliant eyes, the bushy eyebrows, the mouth with a mysterious smile, the speckled beard. We listened to the recitals of his surgical exploits, we even heard him sing, for he sang rather well, in a deep tone.

We listened one evening, at the Congres d'Ophtalmologie Francaise, in a smoke filled coffee room, in which his voice, nearly beyond the tomb, commanded silence and sympathetic admiration.

Liebreich's clinic attracted a world of patients and students. Many teachers and excellent practitioners were formed at his school, for example, Professors Leber of Heidelberg and Laqueur of Strasbourg, who were the chiefs of his clinic.

He taught new things and he taught them well ...

The favor which Liebreich enjoyed was so great that the Emperor sought to create an official chair of ophthalmology for him. But the Faculty of Medicine opposed the plan." 10

An editorial in Annales d'Oculistique described the tense situation which followed the Emperor's proposal: ${ }^{3}$

"An incident, which has suddenly reached unexpected proportions, has placed the Faculty of Medicine of Paris in a state of tension and, with it, some physicians and several of the highest representatives of the mcdical press of Paris: it is simply the question of the proposal by the Emperor to create a special chair of ophthalmology within the Faculty ...

But opposition has extended widely, which is not surprising, if one considers that the position sought was for a foreigner. Xenophobia, as alive in Paris as anywhere, has become excessive. We all understand this susceptibility too well to dream of condemning it, and certainly we act no differently from the rest of the world.

But was it really necessary to propose this honorable practitioner for the new position, and then attack him mercilessly, to make him responsible for a situation that he had not created? We think not, and we deplore

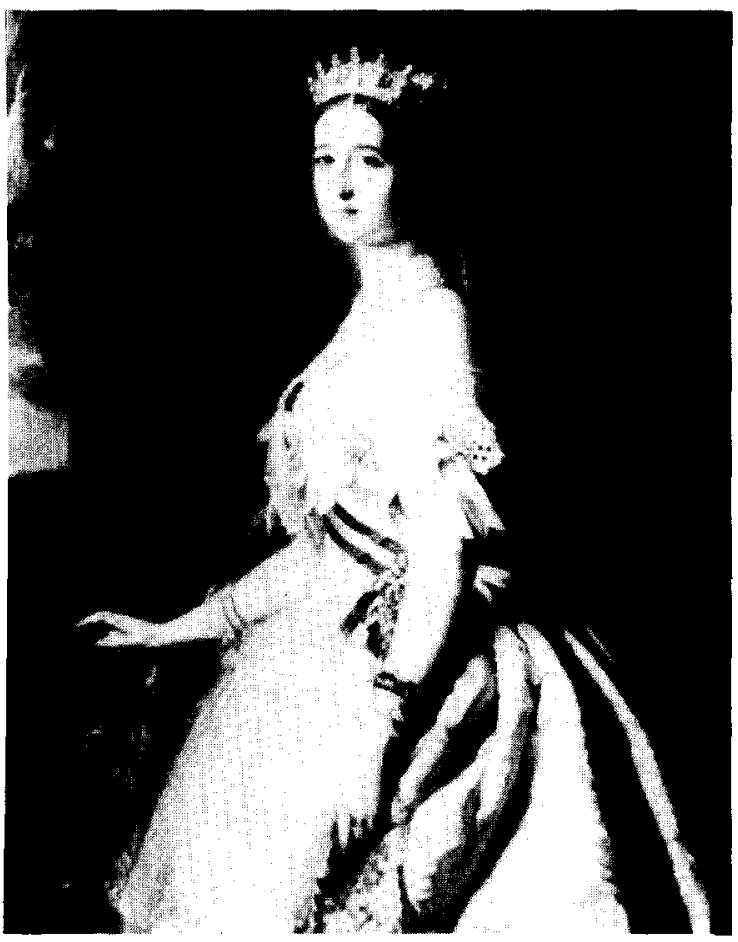

Fig. 6. Aimee Dumas, after F. X. Winterhalter. Empress Eugenie. Oil on canvas, circa 1853. (Collection of Dr. Ravin.)

the lack of discretion and of the most elementary laws of hospitality.

Liebreich (everyone has named him before we have) will escape this assault without much bruising. He was not forced to enter this affair, and without doubt he will decide that it is not necessary for him to defend himself. He will permit us to respond in his place.

Some have repeatedly discredited him for being a foreigner, wanting to make him considered to be an unknown individual. One cannot ignore that as a student of Helmholtz and von Graefe, Liebreich was the witness and several times the actor in great discoveries which have revolutionized ophthalmology during the last few years. He was one of the first to compile important information on ophthalmoscopy, and this was published in 1857, in the French edition of Mackenzie's Traite Practique des Maladies de l'Oeil. This work has been consulted frequently by those who have written on the subject. After having practiced uphthalmoscopy for several years at von Graefe's clinic in Berlin, he published the material in his masterpiece, the Atlas of Ophthalmoscopy, which even his detractors could not avoid admiring; finally, as professor of the ophthalmology clinic in Paris, he has been continuously surrounded by a number of foreign physicians, who enjoy his teaching.

All these titles of fame vanished the day some indi- 
viduals noticed that they could be invoked advantageously for what could be termed "unspeakable pretentions." Since then, Liebreich has become simply an adversary against whom all means of attack are apparently permitted. Some have forgotten that they have had an affair with a gallant man and a first rate practitioner, and they have had no regard or justice for him. These attacks have been painful to us, because those who have made them have forgotten that their adversary, a physician like them and a practitioner distinguished by his titles, has a right to the regard that physicians owe each other ...

For more than 30 years, most of the highest positions in French ophthalmology have been held by German physicians, beginning with Sichel, our master of the field, to whom our sperialty owes the scientific rank which it occupies today, to the young teachers, Liebreich, Edouard Meyer and Wecker, who have come here to serve. Without them, no doubt, ophthalmology in France contains worthy and valiant represcntatives, who would have learned no less in their studies; but the difference which Germany has provided is no less respectable for that, and it is annoying that some people have chosen to misconstrue their value."

\section{The London Years}

Disaster struck with the onset of the FrancoPrussian War in 1870. Although Liebreich was a naturalized French citizen, and was honored by being named a chevalier of the Legion of Honor, he was a Prussian by birth. He was also closely allied with the Emperor, whose government was toppled. Some foreigners, such as de Wecker, managed to stay in France. But Liebreich travelled across the channel to England, as did the French royal family.

Liebreich was only forty, and his distinguished career on the continent was already known in England. St. Thomas's Hospital in London had just completed building its new hospital across the Thames from the Houses of Parliament. Liebreich was offered an appointment as ophthalmic surgeon to the hospital and instructor of ophthalmology in its medical school. Many years later, Sir Anderson Critchett, in British Journal of Ophthalmology, wrote: ${ }^{1}$

"In order to qualify for this it was necessary that he should hold a British surgical degree or diploma, and after an examination, in which, so rumor had it, a generous leniency was extended to the distinguished foreigner, he became a member of the Royal College of Surgeons of England. I have it on the authority of some of his former pupils that he proved to be an excellent teacher, especially on the subject of refraction, although his very limited knowledge of the English language proved a somewhat serious handicap, and in moments of excitement he often lapsed into either French or German."

On February 28, 1871, Liebreich's appointment was confirmed and he was voted the amount of 600 pounds to equip a new department. ${ }^{25}$

But prior to being named to the hospital, I iebreich had to endure another ordeal of editorials against him. Two intensely negative editorials appeared in Lancet, and one on his behalf in the Medical Times and Gazette rebutted Lancet. Hirschberg described the situation:"

"It seems admirable how quickly Liebreich could obtain an important position in London where succeeding, especially for a foreigner, has always been difficult. Already in 1871 he was appointed ophthalmologist and instructor of ophthalmology at the recently built splendid St. Thomas Hospital. He remained in this position for seven years. I visited him there in 1877 , observed his operations, reported on him and defended him against unjustified attacks.

Liebreich had a fortunate talent which enabled him to succeed in Berlin, Paris, and London. He mastered the three languages equally well and had, additionally, talent for singing, painting and sculpturing." [Hirschberg contradicts Critchett on Liebreich's language ability.]

Liebreich resigned from his position at St. Thomas already in 1878, at the age of 48 . The envy and animosity of his London colleagues contributed to this decision.

Their collegial friendship, which I had praised (section 633) did not apply to a foreigner...

His London colleagues reproached him because he visited his cataract patients too often, even already on the evening after the operation. It was claimed that he did this out of greed. I responded and emphasized that he also visited the indigent patients of the hospital. This was the custom in Germany, for the benefit of the patients."

In his letter of resignation in February, 1878, Liebreich noted that his health had forced him to spend most of the long British winters out of the country. ${ }^{25}$

The animosity expressed against him in Lancet was part of a recurrent theme: ${ }^{24}$

"A variety of representations have been made to us in order to deprecate by anticipation our expected criticism of the desire which exists in certain quarters to appoint Dr. Liebreich to the charge of the ophthalmic department of St. Thomas's Hospital. Notwithstanding such appeals, we do not think we shall be generally accused of undue insularity of mind when we protest most strongly, and on principle, against placing any foreigner in such a position. We do so on the broad ground that office in the great hospitals of London is looked to by London men as one of the best and highest rewards for the good and honest work to which it is the incentive, and as a field in which more good and honest work can be carried out. To give this 
reward to a foreigner who has not been resident amongst us, but who was regarded, prior to the proposition, as a mere chance visitor cast upon our shores by the storm of war, seems to involve a neglect or forgetfulness of the good old maxim that people should be just before they are generous. The medical staff of St. Thomas's, in even for a moment encouraging the proposal, acts like the petted heiress, who tries to throw her charms and her fortune into the arms of a whiskered and soi-disant count, and who requires relegation to the nursery and a week upon bread and water in order to restore her to proper senses ...

Our obligation being thus fundamental, it is hardly necessary to refer to minor and collateral issues; but we may, nevertheless, point out that any competition between Englishmen and foreigners for hospital office would often be most unfairly weighted in favour of the latter...

We hold Dr. Liebreich in esteem and respect; and, if it pleases him to remain in London, we trust that he will be saved from his friends, and that he will find here an undisturbed and pleasant resting place. But our esteem for him must not betray us into forgetfulness of duty; and, in the name of the profession in this country, we protest emphatically against a gratuitous and unwarrantable insult to English ophthalmologists. ${ }^{24}$

The Medical Times and Gazette quickly responded: ${ }^{18}$

"The authorities of St. Thomas's Hospital and Medical School have doubtless felt that, with the ample means at their disposal, they were bound to fulfil both functions of a scientific school. These are - to teach what is known and established to beginners and students; and to add to the sum of what is known for the benefit of science and of humanity at large. With this view the Medical staff have selected Dr. Liebreich to fill the chair of Ophthalmology in the school, and the Grand Committee of Governors have recommended him to be elected to the office of Ophthalmic Surgeon to the Hospital. This election and recommendation have been quite unanimous, and no one who knows the state of English and foreign ophthalmology will doubt their wisdom.

Schools of art and science (for the same rule holds good with regard to painting, music, Medicine, and architecture) arise in various countries at different times; they flourish for a while and perhaps attain great excellence, then become barren and decline; they grow so far as permitted by the scientific knowledge and material means available, and then fade like a plant which has exhausted all the nutriment within reach ...

What is true of other branches of scientific art is true of ophthalmology. The English school has attained to a position of great eminence, especially in the operative department; but the Germans have advanced further...

Now, if the English school desires in its turn to become the reigning one, it must begin by assimilating all that Germany can teach ...

Now, just at this moment, when a new Medical school is in the act of organisation, there comes to London, fato profugus, for a temporary shelter from the hazards of war, Dr. Friedreich Richard Liebreich, who, when a student, carried the first ophthalmoscope from Helmholtz to show it to Graefe at Berlin, who has been intimately concerned in every stage of the most advanced ophthalmology, and since the death of Graefe has been the acknowledged leader and representative of the German school. The Medical staff of St. Thomas's seized the opportunity, and without one dissentient voice invited Dr. Liebreich to associate himsclf with them in thcir new school ...

For instance, there is an insinuation about the "whiskered' and soi-disant count; as if Liebreich, a quiet, student-like man, had the character of a stage adventurer, all curls and grease and jewellery. There is an insinuation that Liebreich is not one of the most illustrious of the 'small inner circle of ophthalmologists.' If he be not, who is? There is an insinuation that he cannot speak English; as if a German who has mastered Polish, French, and Spanish, would find much difficulty in perfecting himself in English. .."

But enough of this wretched narrow-mindedness: Liebreich comes amongst us as a Professor and teacher, and we can assure him of a hearty welcome . . "18

The Lancet took up the assault again: ${ }^{23}$

"In our recent observations upon the selection of Dr. Liebreich for the office of ophthalmic surgeon to St. Thomas's Hospital, we expressed a wish that he might be saved from his friends. We regret to find, in the pages of a usually decorous contemporary, an article that shows how completely the wish was called for, and how devoutly Dr. Liebreich himself has by this time occasion to re-echo it . . . we infer, partly from the fact that it contains nearly as many grammatical errors as lines, partly from the fact that the writer uses common words erroneously - as a charwoman might do ... partly from an ignorance about the points discussed so abysmal as to be inconceivable in a journalist ... and partly from a general tone of vulgarity which we cheerfully admit to be wholly foreign to the place in which it is displayed.

The small inner circle of ophthalmologists was for some years composed of three men, von Graefe, Donders, and Bowman. In a second circle around them would be ranged others ... Then in a third circle, very well represented in this country, we find a large number of men who have written meritoriously upon some single subject - who have produced a good monograph or treatise. Among these we should place Dr. Liebreich; for although his repute rests on the skill with which he has painted accurate pictures of disease, rather than on any work which can be strictly called scientific, yet there can be no doubt that these pictures have been of much practical value, and that they are worthy of high commendation. When we ask what else he has done, what is the reply? He has suggested a modified fashion of operating for squint, he 
has devised iris forceps which, like the famous patent corkscrew, are quite as good as the old ones, and do not give much more trouble; and he has contrived portable and convenient forms of Ruete's ophthalmoscope. This is absolutely all, with the exception of a very few short and unimportant contributions to ophthalmological literature ... Dr. Liebreich's position among the luminaries of the third order is so respectable, and has been so fairly won, that it is painful to be forced into this precise definition of it by the unscrupulous attack to which we have referred." ${ }^{23}$

What prompted all these diatribes against Liebreich? Was it truly because he was a foreigner in Paris and in London? And a Prussian to boot? Sadly, but not surprisingly, there is more to this story. Landolt said that Liebrcich, with his long narrow face and circles under the eyes, looked like Shylock. ${ }^{10}$ Hirschberg defended Liebreich against charges of being "clumsy like a Polish Jew." Liebreich was Jewish by birth. He may have converted to the Protestant faith later in life. ${ }^{9,20} \mathrm{He}$ appears to have left no direct descendants. His younger brother, Oscar, was a distinguished pharmacologist and a founder of the pharmacological institute in Berlin. Oscar's son survived the Nazi regime, but with great difficulty. Among other things, Liebreich may very well have suffered from religious persecution.

Barriers to advancement due to religion were common during the last century. To cite just one more example, consider the case of Sichel, the great French ophthalmologist of the early years of the 19th century. He converted from Judaism to the Protestant faith in order to avoid the barriers in his path. He was highly successful in his practice, an innovator, a prolific author, even decorated by the King. But despite his achievements, he was denied membership in the Academy of Medicine and never made a professor.

\section{Return to Paris}

After spending seven years in London, Liebreich returned to Paris, where he resumed his private practice. ${ }^{21}$ According to Hirschberg, "Some of his wealthy patients would swear that he was the only one on earth who could select a difficult pair of glasses for them." Landolt wrote, "Patients were very attached to him, loved him, even venerated him ... but the principal reasons of his success were without doubt the seriousness and competence with which he examined them, the interest which he showed." 10

While in London he had given three influential lectures on art that were later published in England and in France. These have been the subject of scholarly discussion ever since. They were: Turner and Mulready - On the Effect of ccrtain Faults of Vision on Painting, with especial Reference to their Works (1872); ${ }^{19}$ On the Real and Ideal in Portraiture (1875); ${ }^{13}$ and The Deterioration of Oil Paintings (1878). ${ }^{12}$

Liebreich eventually retired from the practice of medicine and devoted himself only to the fine arts. Hirschberg says he saw Liebreich once more in the 1880s in Catania, Sicily, "but never visited him in Paris because he was thought to be somewhat of a hermit and he never again attended an ophthalmological meeting." on the 50th anniversary of his graduation from medical school, Liebreich returned to Halle to give a presentation and to receive an honorary degree. $^{9}$

Landolt's ${ }^{10}$ version of Liebreich's return to Paris is a bit different from Hirschberg's:

"After having achieved sufficient affluence to live independently, he left London and returned to Paris. But this time he installed himself on the other side of the Seine. He changed his world and his milieu. He became the confrere of, and mixed with, artists.

I heard several times from his colleagues of the palette that this new and singular companion had emerged among them. They respected him, because he astonished them. He told them of things they had never heard before and of which they knew nothing. In abandoning ophthalmology for the fine arts, he did not leave scientific terrain. His ambition was not to become a Raphael or a Titian, but to rediscover the colors which the old masters used for their masterpieces.

That was not sufficient to make him their equal, but he sought to render an immense service to modern painters, whose beautiful works, were changing, peeling away, disappearing before our eyes, because of the instability of the colors of which they were composed ... It is likely that his brother Oscar, an important chemist, helped him in his research.

By all means, Liebreich never cast off the man of science, the ophthalmologist, in his peregrinations in the artistic domain. For example, he sought an explanation for the strange changes which befell the great English painters Turner and Mulready with advancing age. [Mulready, an Irishman, would not have wanted to be called English.] He attributed this to optical defects, astigmatism in one, a yellow coloration of the lens in the other.

For a long time at the National Gallery one could see people furnished with cylindrical lenses and blue glasses, profoundly impressed by the findings of the German savant who tried to compensate for the errors and extravagances of their great national painters.

I do not know exactly what service he was able to render to the arts, but yet, I know that as previously in ophthalmology, he was a stimulator of ideas, a creator of new views, original and prolific." 10

Landolt met Liebreich in his studio in 1881. 
He saw two marble busts Liebreich had created, and complimented him. Liebreich's response was, "Ah! I used to sculpt, but I have abandoned it completely. Nothing which presents so much difficulty can maintain its interest for me. Now, as you see, I am painting." ${ }^{10}$ Liebreich was seated in front of an enormous canvas on which he had painted a goddess with wings.

In 1893 Liebreich attended the International Congress of Ophthalmology, at which he exhibited the portrait he had painted of von Graefe. Professor Wolfgang Jaeger has tried to find the present location of this painting, but even von Graefe's descendants do not know of its whereabouts.

Liebreich died in Paris in 1917, at the venerable age of 86. As Landolt concluded in his necrology, "Liebreich was a man of great intellectual valor whose influence was valuable in all the domains in which he lived."10

\section{References}

1. Critchett A: Richard Liebreich. Br J Ophth 1:208-210, 1917

2. Derby H: Personal recollections of Graefe, Arlt, and Donders. Arch Ophthalmol 2:237-255, 1919

3. Editorial: Ann Ocul 54:315-316, 1865

4. von Haugwitz T: The History of Optical Instruments for the Examination of the Eye. FC Blodi (trans): Hirschberg's History of Ophthalmology, 11:A5, Bonn, Wayenbourg, 1986

5. Ibid, 11:A113

6. Ibid, 11:A25

7. Hirschberg J: Richard Liebreich, Geschicte der Augenheilkunde, FC Blodi (trans): Handbuch der Gesamten Augenheilkunde v Graefe und Saemisch XV, 1, pp 10-16. Berlin, Springer, 1918

8. Jaeger W: Theodore Leber's studies in Paris (18641867) as an assistant of Richard Liebreich. Doc Ophthalmol 77:269-276, 1991
9. Kaiser W: FR Liebreich. Wiss Z Univ Halle 22:89-94, 1973

10. Landolt E: Necrologie, R Liebreich, Arch Ophtalmol 35: 508-512, 1917

11. Liebreich R: Atlas der Ophthalmoscopie. Berlin, Hirshwald and Paris, Germer Balliere, 1863

12. Liebreich R: The deterioration of oil paintings. Notes and Proceedings Roy Inst GB 8:514-526, 1879

13. Liebreich R: On the real and ideal in portraiture. Notes and Proceedings Roy Inst GB 7:430-443, 1875

14. Liebreich R: Ophthalmoskopsiche Notizen. Arch Ophthalmol I, 2;333-356, 1854/IV, 2; 286-303,1858/V, 2; 241-268, 1859/VII, 2; 124-135, 1860

15. Liebreich R: Photographie des Augengrundes. Allgem Med Central - Zeitung, 1858

16. Liebreich R, Laqueur L: Recueil des Travaux de la Societe Allemande de Paris. Masson, 1865

17. Liebreich R: Retinitis pigmentosa. Deutche Klin No 6, 1861

18. Dr Liebreich at St. Thomas's Hospital (editorial): Medical Times and Gazette 1:250-251, 1871

19. Liebreich R: Turner and Mulready - On the effect of certain faults of vision on painting, with especial reference to their works. Not Proc Roy Inst GB 6:450-463, 1875

20. Mawas E: Europe medicale d'avant-hier et peut-etre de demain, Beitrague zur Geschichte der Augenheilkunde. Vienna, Facultas Universitats Verlag, 1991, pp 15-24

21. Miller H: En hommage à la memoire du Dr Liebreich et de mon pere, A V Miller. Beitrage zur Geschichte der Augenheilkunde. Vienna: Facultas Universitats Verlag, 1991, pp 23-24

22. Ronall JO: Ludwig Bamberger. Encyc Judaica. Jerusalem, Ketter 4:153-154, 1972

23. Save Me from My Friends (editorial): Lancet 1:352-353, 1871

24. St Thomas's Hospital and Dr Liebreich (editorial): Lancet $1: 274-275,1871$

25. Winstanley J: Ophthalmology at St Thomas's Through Three Centuries. Privately printed, 1971, p 22

The assistance of Frederick Blodi, M.D., Iowa City, Iowa, and of Professor Wolfgang Jaeger, Heidelberg, Germany, is gratefully acknowledged.

Reprint address: James G. Ravin, M.D., 3000 Regency Ct., Suite 100, Toledo, OH 43623.

INDEX OF ADVERTISERS

November-December 1992

\begin{tabular}{|c|c|}
\hline Alcon Laboratories ............... Cover 2, 1a, 2a & Ophthalmic Reviews ....................... 10a, 11a \\
\hline Escalon Ophthalmics ................................... & Staar Surgical ..................... \\
\hline Kowa Optimed ...................................... 12a & Storz Ophthalmics $\ldots . . \ldots \ldots \ldots \ldots \ldots \ldots \ldots \ldots$ Cover 4 \\
\hline
\end{tabular}

OMS $8 a, 9 a$ 